\title{
FINANCIAL STABILITY OF ISLAMIC AND CONVENTIONAL BANKS IN BANGLADESH: REVISITING STABILITY MEASURES AND ANALYZING STABILITY BEHAVIOR
}

\author{
Md. Enayet Hossain ${ }^{1}$ \\ Mahmood Osman Imam ${ }^{2}$
}

\begin{abstract}
This study intends to assess the relative financial stability of Islamic banks in Bangladesh using three different Z-Scores as financial stability measures, based on a sample of 29 listed commercial banks (23 conventional and 6 Islamic) in Bangladesh over the period 2005-2016. Apart from the existing measure of financial stability, Z-Score, the paper contributes to the literature by developing an alternative Z-Score based on bank's loan portfolio infection ratio. We first use pair-wise comparison and find that Islamic banks are financially more stable in two stability measures i.e. Z-Score (based on Capital Adequacy Ratio) and Z-Score (based on Infection Ratio). We then perform static (random effects) and dynamic (GMM) panel data analysis. By controlling for bankspecific, industry-specific and macroeconomic variables in the regressions, we find that Islamic banks are financially more stable in 2 panel regressions of Z-Score (based on Infection Ratio). We also find that the presence of Islamic banks increases the stability of all banks in the system including their conventional peers.
\end{abstract}

Keywords: Financial Stability, Financial Stability Measures, Z Scores, Z Scores based on CAR, Z Scores based on IR, Islamic Banking

JEL Classification: G20, G21, 043

Received: September 17, 2017; Revised: January 15, 2018;

Accepted: February 15, 2018

1 Research Associate, Department of Finance \& Market Analyst, Credence Asset Management Limited, enayet_fin17b@yahoo.com

2 Professor of Finance, Department of Finance, University of Dhaka, osman@du.ac.bd 


\section{INTRODUCTION}

The number and size of Islamic banks are growing rapidly worldwide and the Islamic banking industry is not lagging behind (in terms of growth) in Bangladesh too. The asset growth (CAGR) of Islamic banks in Bangladesh is $20 \%$ over the last 12 years, whereas that of conventional banks is $18 \%$. Currently the country's full-fledged Islamic banks controls 20\% of total banking assets of the country and the market share has consistently kept on increasing since 2002. The literature on Islamic banking in Bangladesh is also growing mostly in the area of comparison between these two (modes) types of banking in terms of efficiency, profitability, liquidity and impact of financial crisis on stability. Empirical papers on financial stability of banks are based on specific regions or on a global basis, most of which find significant country specific differences in financial stability. This motivates us to examine empirically the financial stability of Islamic banks in Bangladesh, which is non-existent as of today.

Čihák \& Hesse, (2010) empirically analysed the financial stability of Islamic banks in 20 banking systems, on a cross country basis. Using Z-score they find that (i) Islamic banks of smaller size are financially more stable than those of larger size and conventional banks of smaller size and (ii) large conventional banks are financially more stable than large Islamic banks. One of the reasons for more financial stability of Islamic banks, they argue, is in risk-sharing transfer arrangements that enable Islamic banks to shift a loss on the asset side (e.g. Musharaka loss) to the liability side (Mudaraba mode of deposits). Another explanation is that all three issues call for providing competitive yield to investors (banks and firms), operational risk associated with PLS arrangement and difficulty in access to liquidity makes the Islamic banks conservative. This eventually reduces moral hazard problem and risk taking behaviour. However, the reason for less stability for large Islamic banks might be the complexities in credit risk management, monitoring of PLS agreements and high-risk investments.

The finding of Rajhi \& Hassairi (2013) is different from that of Čihák \& Hesse (2010). Rajhi \& Hassairi (2013) analysed 16 banking systems in MENA and South East Asian countries and found that Islamic banks have high Z-scores i.e. more financial stability, than conventional banks (except small Islamic banks). They find country or region specific differences in and reasons for financial stability. For small and large Islamic banks, income diversity is a factor of stability in MENA countries, while it becomes inverse in South East Asian countries. 
Bourkhis \& Nabi (2013) analysed the financial soundness of Islamic banks during the 2007-08 financial crisis using Z-Score and ratio analysis and find no significant difference in soundness of the two types of banks.

Abedifar, Molyneux, \& Tarazi (2013) analysed banks from 24 countries over the period 1999 to 2009 and using Z-Score (based on CAR) find that with higher equity capitalization, Islamic banks of smaller size have shown more resilience than conventional banks of smaller size. They find virtually no difference in terms of stability for large Islamic- and conventional banks. Their results show that loan quality of Islamic banks is less sensitive to interest rates compared to conventional banks.

Beck, Demirgüç-Kunt, \& Merrouche (2013) analysed banks from 22 countries over the period 1995 to 2009 and using Z-Score (based on CAR) find that there is no significant difference in financial stability of Islamic banks and conventional banks during this period and the financial crisis of 2007-08.

Farook, Hassan, \& Clinch (2015) analysed 50 Islamic banks and 150 conventional banks and finds almost similar result as that of čihák \& Hesse (2010). They find no evidence suggesting Islamic banks' less financial stability. Moreover, they find small-sized Islamic banks to be financially more resilient than their conventional peers and large-sized Islamic banks to be financially less resilient.

A recent study by Uddin, Chowdhury, \& Islam (2017) examines the resilience of Islamic and conventional banks in Bangladesh during the financial crisis of 2007-08. Based on a sample of 25 commercial banks in Bangladesh during 2005 to 2014, they find that Islamic banks were more resilient during the crisis period.

The literature does not give a clear indication of whether Islamic banks are financially more or less stable than their conventional peers and also is not in consensus about the appropriate measure of financial stability. Moreover, the literature on financial stability on Bangladesh perspective focuses on the stability and performance comparison of the two bank type during the financial crisis of 2007-08 with fewer observation period and control variables (Uddin et al., 2017).

This study is aimed to address the gap in the empirical literature on Islamic banking in Bangladesh and also to develop an alternative Z-Score which is expected to measure financial stability well. This is the first study on the overall financial stability of Islamic and conventional banks in Bangladesh where all the listed banks have been considered and a more 
intuitively strengthened financial stability measure has been used. We use three types of measures of financial stability and find that Islamic banks are financially more stable in two measures i.e. Z-Score (CAR) and Z-Score (IR). Moreover, the presence of Islamic banks increases financial stability in the banking system and also increases the financial stability of conventional banks. This may indicate that Islamic- and conventional banks can coexist in the similar banking system elsewhere, Bangladesh in particular.

The structure of the study is as follows. A synopsis of Islamic banking and specific risks inherent in it is given in section 2 . The financial stability of banks in defined in section 3. In section 4, the methodology, variables and data description is discussed. Section 5 discusses the empirical results of the study. Section 6 concludes and suggests opportunity for further research.

\section{THE CONCEPT OF ISLAMIC BANKING}

Islamic banking is established on several principles the most prominent of which are the prohibition of interest (Riba) in lending and borrowing activities, the prohibition of financing illicit activities or business or products, and the prohibition of speculation. The rationale for charging interest is that money is only a medium of exchange and cannot have a price for itself. On the other hand, Sharia-compliant products are based on profit and loss sharing (PLS) and thereby risk sharing and all the transactions are backed by real assets. Moreover, the use of derivative products for speculation and arbitrage except hedging is also not allowed by Islamic financial institutions (Jobst, 2008). This suggests a clear distinction between the conventional and Islamic banking. However, the Islamic equivalent of various conventional financial products have emerged and some are raising controversy too.

In PLS financing, the rate of return is not known in advance by any party. The speciality of PLS financing is that the loss on the asset side of the balance sheet can be absorbed completely on the liability side and thus making Islamic banks avoid or at least minimize any financial distress. Moreover, credit risk on the asset side can also be shifted to the investment depositors. But with no collateral or guarantees backing the PLS transactions, the credit risk may also increase.

In purchase and resale transaction, a mark-up is added to the cost of the product and the transaction is backed by real assets. The backing of transactions by real assets reduces leveraging and speculative behaviour that may cause instability. However, Islamic banks may deviate from these 
principles in an effort to compete with and mimic conventional banks. Thus Islamic banks may be exposed to risks that they are not supposed to be exposed to. The deviations evidenced in some studies is as follows:

a) Asset composition-Typical Islamic banks have around $80 \%$ of total assets as short-term and fixed income assets and $20 \%$ as long-term and risk-sharing investments (Bourkhis \& Nabi, 2013). The tendency for Islamic banks to get involved more in mark-up transactions and less in PLS transactions deprives them of both the benefits of diversification and high risk-high return investments.

b) Profit Distribution - In an effort to pay competitive rates to investment depositors, Islamic banks sometimes distribute profits from equity when they incur loss, a phenomenon called displaced commercial risk (Van Greuning \& lqbal, 2008).

c) Compliance with Sharia Principles - Chong \& Liu (2009) finds that Islamic banks in Malaysia does not practice PLS modes of financing very often and the deposits are tagged with interest rates and thus Islamic banking principles are least practiced in Malaysia.

The question of whether Islamic banks in Bangladesh are more or less resilient than their conventional peers is at the core of our study. But the existing literature is not endowed with an unambiguous answer. Apart from the existing measure of financial stability, Z-Score, the paper contributes to the literature by developing an alternative Z-Score based on bank's loan portfolio infection ratio. The very purpose of the remaining part of the study is to determine whether Islamic banks are able to show more resilience than their conventional peers in Bangladesh, using a new measure of stability, i.e. modified Z score based on infection ratio.

\section{THE FINANCIAL STABILITY OF A BANK}

The concept of financial stability can be clarified in many ways. According to Allen \& Wood (2006), financial stability is a period characterized by the absence of instability where the market participants undergoes financial crises not justified by their previous behaviour. So, financial stability is a period where the probability that financial stability comes is minimal. During a period of financial stability, the financial intermediation process occurs smoothly and the confidence in the financial intermediaries is very high.

European Central Bank (2015) define financial stability as "A condition in which the financial system - intermediaries, markets and market infrastructures - can withstand shocks without major disruption in 
financial intermediation and in the effective allocation of savings to productive investment". So we can summarize bank financial stability as a condition or situation where banks have the financial strength to withstand financial shocks and can operate profitably, efficiently and with confidence.

\section{METHODOLOGY AND DATA \\ 4.1 Measuring Bank Financial Stability}

Z-score (based on ROAA) is a popular measure of financial stability in the literature, which has been followed in these previous studies (Abedifar et al., 2013; Beck et al., 2013; Boyd \& Runkle, 1993; Čihák \& Hesse, 2010; Laeven \& Levine, 2009; Lepetit, Nys, Rous, \& Tarazi, 2008; Maechler, Mitra, $\&$ Worrel, 2005). Moreover, we will use 2 variants of z-score in our dependent variables as a proxy for financial stability of individual bank.

\subsubsection{Z-Score (ROAA)}

Z-Score measures the number of standard deviations that a bank's return on average assets (ROAA) has to fall below its mean value to deplete equity and force the bank towards insolvency.

$$
\mathrm{Z}=(\mathrm{k}+\mu) / \sigma
$$

Where, $\mathrm{k}=$ Equity capital and reserves as percent of assets

$\mu=5$-year moving average of Return On Average Assets (ROAA)

$\sigma=5$-year moving average standard deviation of ROAA

Z-Score is negatively associated with a bank's insolvency risk. Insolvency occurs when a bank's asset value falls short of its debt level. The insolvency probability can be written as $\mathrm{P}(\mathrm{ROAA}<-K)$. If standardized ROAA is used, the probability is $P\left(\frac{\mathrm{ROAA}-\mu}{\sigma}<-Z\right)$ or $P\left(\frac{\mu-\mathrm{ROAA}}{\sigma}>Z\right)$. Hence the Z-Score measures the number of standard deviations that a bank's return (ROAA) has to decline below its mean value to deplete equity and force the bank towards insolvency. The higher the Z-Score, the greater the financial stability of a bank (Abedifar et al., 2013).

\subsubsection{Z-Score (CAR)}

Here, the only modification made to Z-Score is the use of CAR (Capital Adequacy Ratio) instead of equity-asset ratio. The rationale is that CAR is a more reliable estimate of the equity position of a bank than the equity-asset 
ratio. This has been already been used in empirical literature (Abedifar et al., 2013).

$$
Z=(k+\mu) / \sigma
$$

Where, $\mathrm{k}=$ Capital adequacy ratio (CAR)

$\mu=5$-year moving average of Return on Average Assets (ROAA)

$\sigma=5$-year moving average standard deviation of ROAA

\subsubsection{Z-Score (IR)}

We introduce a Z-Score based on Infection Ratio (IR) which is defined as:

$$
\text { Infection Ratio, IR }=\frac{\text { Net NPL+Cumulative Loan Writen off }}{\text { Total Loans+Cumulative Loan Writen off }}
$$

With banks in Bangladesh having around $70 \%$ of their assets comprising of loans, the risk of the loan portfolio is expected to contribute to the banks' financial stability to a significant extent. The IR can be very effective in measuring the quality of a bank's loan portfolio as it adjusts the NPL ratio by deducting the cumulative specific provision maintained and also takes into account the cumulative amount of loans written off from the bank's balance sheet. In this way, the whole picture of the bad assets existing in banks' loan portfolio is reflected in IR. Thus, an alternative measure based on IR is expected to provide a better measure of financial stability of a bank than the existing measures. Hence, we built a Z-Score that incorporates infection ratio.

The rationale for the Z-Score based on IR is that Insolvency occurs when where,

$$
\mathrm{K}=\frac{\text { Regulatory Capital, } \mathrm{RC}}{\text { Total Loans+Cumulative Loan Writen off }}
$$

After standardizing $I R$ and $K$, the probability takes the form as $\mathrm{P}\left(\frac{I R-\mu}{\sigma}>\right.$ $\frac{K-\mu}{\sigma}$ ) where,

$$
\begin{aligned}
& \mu=5 \text {-year moving average of Infection Ratio (IR) } \\
& \sigma=5 \text {-year moving average standard deviation of IR } \\
& Z=(k-\mu) / \sigma
\end{aligned}
$$

Hence the Z-Score based on IR measures the number of standard deviations that a bank's Infection Ratio (IR) has to exceed its mean value to deplete Regulatory Capital and force the bank towards insolvency. In this case too, the higher the Score, the greater the financial stability of a bank. 


\subsection{Why can Z-Score (based on IR) be a Better Measure than other Z- Scores?}

A major component of the Z-Score formula is the standard deviation in the denominator, which affects the Z-Score significantly. The consistent low ROAA of some of the banks in the study on a recent time period depicts low volatility of ROA and thereby making the Z-Score (ROAA) and Z-Score (CAR) to be high. This high Z-Score is counter intuitive to the actual stability situation of the bank. This consistency in low ROAA also depicts the deterioration of asset quality, which would be better captured by Z-Score (IR) that takes into account of the infection ratio (IR) and standard deviation of IR instead of ROAA.

This situation can be explained by the example of one (Al-Arafah Islami Bank Ltd.) of such banks in the sample.

Table 1.

Z-Score (ROAA) of Al-Arafah Islami Bank Ltd.

\begin{tabular}{lrrrrrc}
\hline & 2011 & 2012 & 2013 & 2014 & 2015 & 2016 \\
\hline ROAA & $2.43 \%$ & $1.56 \%$ & $1.41 \%$ & $1.19 \%$ & $1.12 \%$ & $1.33 \%$ \\
$\begin{array}{l}\text { 5-year moving average } \\
\text { Standard deviation of }\end{array}$ & & & & & 0.0047 & 0.00154 \\
ROAA & & & & & \\
$\begin{array}{l}\text { 5-year moving average } \\
\text { of ROAA }\end{array}$ & & & & $1.54 \%$ & $1.32 \%$ \\
Equity-Asset Ratio & & & & $7.65 \%$ & $7.19 \%$ \\
Z-Score (ROAA) & & & & 19.542 & 55.154 \\
\hline
\end{tabular}

The improvement in the Z-Score of Al-Arafah Islami Bank Ltd. in 2016 might imply that the bank's stability situation improved in the year. But observing the decline in the 5-year average ROAA and the Equity-Asset ratio, the increase in Z-Score by around $182 \%$ is hardly justified. Though the ROAA in 2016 has slightly increased, the increase in Z-Score is mainly driven by the low 5-year moving average standard deviation of ROAA caused by the drop of a better ROAA in 2011.

In our view, the Z-Score (IR) better captures the stability change of this bank in 2016. 
Table 2.

Z-Score (IR) of Al-Arafah Islami Bank Ltd.

\begin{tabular}{|c|c|c|c|c|c|c|}
\hline & 2011 & 2012 & 2013 & 2014 & 2015 & 2016 \\
\hline IR & $1.4 \%$ & $2.1 \%$ & $2.6 \%$ & $5.1 \%$ & $5.2 \%$ & $5.22 \%$ \\
\hline $\begin{array}{l}\text { 5-year moving } \\
\text { average standard } \\
\text { deviation of IR }\end{array}$ & & & & & 0.01583 & 0.01399 \\
\hline $\begin{array}{l}\text { 5-year moving } \\
\text { average of IR }\end{array}$ & & & & & $3.3 \%$ & $4.0 \%$ \\
\hline $\begin{array}{l}\text { Regulatory Capital to } \\
\text { the sum of total loan } \\
\text { and loan written off }\end{array}$ & & & & & $12.9 \%$ & $11.8 \%$ \\
\hline Z-Score (IR) & & & & & 6.083 & 5.557 \\
\hline
\end{tabular}

The score of the bank in this measure has declined in 2016 implying that the stability of the bank has declined. This can be justified by the decline in the capital component in the score from $12.9 \%$ to $11.8 \%$ and increase in the average infection ratio (IR) from 3.3\% to $4.0 \%$. The bank's CAR also declined in 2016 from $15.3 \%$ to $14.4 \%$. Its asset quality in terms of IR has also declined as indicated by an increase from $5.2 \%$ to $5.22 \%$. So, the stability of the bank has not improved in 2016 . Its stability actually deteriorated in the year, which has been captured by a decline in Z-Score (IR). This makes a strong case for this Z-Score (IR) to be a better alternative measure of financial stability of banks.

\subsection{Panel Data Analysis - Static and Dynamic}

We use the regressions of the measures of financial stability as a function of some explanatory and control variables. The panel model takes the following form:

$$
\begin{gathered}
\text { LogZScore }_{i, t}=\alpha+\beta B_{i, t-1}+\gamma I_{t-1}+\sum \delta_{s} T_{s}+\sum T_{s} I_{t-1}+\omega M_{t-1}+D_{t}+\varepsilon_{i, t} \\
\text { LogZSCoreCAR }_{i, t}=\alpha+\beta B_{i, t-1}+\gamma I_{t-1}+\sum \delta_{s} T_{s}+\sum T_{s} I_{t-1}+\omega M_{t-1}+D_{t}+\varepsilon_{i, t} \\
\text { LogZSCorelR }_{i, t}=\alpha+\beta B_{i, t-1}+\gamma I_{t-1}+\sum \delta_{s} T_{s}+\sum T_{s} I_{t-1}+\omega M_{t-1}+D_{t}+\varepsilon_{i, t}
\end{gathered}
$$

Where,

LogZScore $_{i, \mathrm{t}} \quad=$ Log of Z-Score based on ROAA for bank $\mathrm{i}$ at time $\mathrm{t}$ LogZScoreCAR $R_{i, t}=\log$ of Z-Score based on CAR for bank $i$ at time $t$ LogZScoreIR $\mathrm{i}_{\mathrm{i}} \quad=$ Log of Z-Score based on Infection Ratio (IR) for bank $\mathrm{i}$ at time $t$ 


$\begin{array}{ll}\mathrm{B}_{\mathrm{i}, \mathrm{t}-1} & =\text { Vector of bank-specific variables } \\ \mathrm{I}_{\mathrm{t}-1} & =\text { Time-varying industry-specific variables } \\ \mathrm{T}_{\mathrm{s}} & =\text { Type of banks } \\ \mathrm{T}_{\mathrm{s}} \mathrm{t}_{\mathrm{t}-1} & =\text { The interaction between bank type and } \\ \text { specific variables } & \\ \mathrm{M}_{\mathrm{t}-1} & =\text { Vector of macroeconomic variables } \\ \mathrm{D}_{\mathrm{t}} & =\text { Vector of yearly dummy variables } \\ \varepsilon_{\mathrm{i}, \mathrm{t}} & =\text { Residual }\end{array}$

The impact of each type of bank on the measures of financial stability is distinguished with help of the dummy variable which takes the value between 1 (for Islamic banks) and 0 (for conventional banks). A positive sign for the Islamic dummy variable in the regression would indicate the relative resilience of Islamic banks.

The regressions include various control and explanatory variables at the bank-specific, industry-specific and macro level. At the bank level, we control for several bank-specific differences in size (in terms of assets), asset composition, efficiency, deviation from traditional lending activities by including log of total assets, loan-asset ratio, cost-income ratio, income diversity (Laeven \& Levine, 2009).

At the industry level, we calculate Herfindahl-Hirschman Index which is the sum of squared market shares (in terms of total assets) of all banks (banks listed in Dhaka Stock Exchange and State-owned banks) in the country. We also examine the impact of Islamic bank on other banks by calculating the total market share of all Islamic banks for each year and interacting it with conventional bank dummy.

At the macro level, we control for the impact of macroeconomic level variables real rate of GDP growth and of inflation. Moreover, yearly dummy variables have also been included in the regressions to control for the time effect.

All explanatory and control variables bank-specific, industry, macroeconomic variables and interaction terms with the bank dummies are lagged by one year to remove endogeneity. We use the GLS Random Effects regression and control for outliers by taking log of the dependent variables and total assets. For dynamic analysis of financial stability behaviour, we also use Dynamic Panel Regressions. 


\subsection{Data}

Our study includes individual bank consolidated data hand-collected from the annual reports of each bank. We include all the listed commercial banks (Excluding ICB Islamic Bank) in our sample which consists of 23 conventional banks and 6 full-fledged Islamic banks. For the calculations of market shares of each bank, we also take into account the market share of 3 non-listed state-owned commercial banks i.e. Sonali, Janata, Agrani along with the 29 banks in our sample. Our regressions include measures of financial stability for each bank from 2005 to 2016.

Table 3.

Data

\begin{tabular}{lcccc}
\hline & All Banks & Islamic Banks & $\begin{array}{c}\text { Conventional } \\
\text { Banks }\end{array}$ \\
\hline Number of Banks & & 29 & 6 & 23 \\
$\begin{array}{l}\text { Number of } \\
\text { Observations }\end{array}$ & Banks' & 348 & 72 & 276 \\
\hline
\end{tabular}

\subsubsection{List of Variables}

The details of the variables are listed below:

Table 4.

\section{List of Variables}

\begin{tabular}{|c|c|c|c|}
\hline & Variables & Definition & Description \\
\hline & $\begin{array}{l}\text { Log Z-Score } \\
\text { (ROAA) }\end{array}$ & $\begin{array}{l}\text { Defined as } \log Z=(\mathrm{k}+\mu) / \sigma \text {, where } \mathrm{k} \\
\text { is equity as percent of assets, } \mu \text { is } 5- \\
\text { year moving average ROAA and } \sigma \text { is } \\
5 \text {-year moving average standard } \\
\text { deviation of ROAA and measures the } \\
\text { number of standard deviation that a } \\
\text { bank's return has to fall below its } \\
\text { average value to deplete equity and } \\
\text { make the bank insolvent }\end{array}$ & Measure of Financial Stability \\
\hline
\end{tabular}

\begin{tabular}{|c|c|c|c|}
\hline & Variables & Definition & Description \\
\hline 2. & $\begin{array}{l}\text { Log } \\
\text { Score } \\
\text { (CAR) }\end{array}$ & $\begin{array}{l}\text { Z- } \quad \text { Defined as } \log Z=(k+\mu) / \sigma, \text { where } k \\
\text { is capital adequacy ratio (CAR), } \mu \text { is } \\
5 \text {-year moving average ROAA and } \sigma \\
\text { is 5-year moving average standard } \\
\text { deviation of ROAA and measures the }\end{array}$ & Measure of Financial Stability \\
\hline
\end{tabular}


number of standard deviation that a bank's return has to fall below its average value to deplete equity and make the bank insolvent

3. $\log$ Defined as $\log Z=(k-\mu) / \sigma$, where $k$
Score $(I R) \quad$ is the ratio of $R C$ to the sum of loans and loans written off, $\mu$ is 5-year moving average $I R$ and $\sigma$ is 5-year moving average standard deviation of $I R$ and measures the number of standard deviation that a bank's Infection Ratio (IR) has to exceed its mean value to deplete Regulatory Capital and force the bank towards insolvency

\section{a. Bank Specific Variables}

\begin{tabular}{|c|c|c|c|}
\hline 4. & Log Assets & $\begin{array}{l}\text { Log of total assets of a bank (mn } \\
\text { BDT) }\end{array}$ & Bank size \\
\hline 5. & $\begin{array}{l}\text { Loan- } \\
\text { Assets } \\
\text { Ratio }\end{array}$ & Ratio of loans to assets (percent) & Asset composition \\
\hline 6. & $\begin{array}{l}\text { Cost- } \\
\text { Income } \\
\text { Ratio }\end{array}$ & Ratio of cost to income (percent) & Cost efficiency \\
\hline 7. & $\begin{array}{l}\text { Income } \\
\text { Diversity }\end{array}$ & $\begin{array}{l}1-((\text { Net Interest Income-Other } \\
\text { Operating Income }) / \text { Total Operating } \\
\text { Income })\end{array}$ & $\begin{array}{l}\text { Diversity of a bank's income } \\
\text { sources }\end{array}$ \\
\hline
\end{tabular}

\section{b. Industry Specific Variables}

8. Share of Market share of Islamic banks (in Islamic banks' impact on other Islamic terms of Assets) per year banks

Banks

9. Herfindahl- Sum of squared market shares of Possible impact of banking Hirschman banks in the system sector concentration on riskIndex (HHI) taking behavior

10. Share of Islamic Banks*Co mmercial (Conventio nal) Bank Dummy
Interaction of share of Islamic banks and the Conventional bank dummy
Novo Measure of Financial Stability 


\begin{tabular}{|c|c|c|c|}
\hline \multicolumn{4}{|c|}{ Dummy Variables } \\
\hline $\begin{array}{l}\text { 13. Islamic } \\
\text { Bank } \\
\text { Dummy }\end{array}$ & $\begin{array}{l}\text { Takes the value of one (1) for Islamic } \\
\text { banks, otherwise zero (0) }\end{array}$ & $\begin{array}{l}\text { Dichotomous } \\
\text { bank type }\end{array}$ & Classification of \\
\hline $\begin{array}{l}\text { 14. Yearly } \\
\text { Dummy } \\
\text { Variables }\end{array}$ & & $\begin{array}{l}\text { Controlling } \\
\text { unobserved } \\
\text { effects. }\end{array}$ & $\begin{array}{r}\text { potential } \\
\text { time-varying }\end{array}$ \\
\hline
\end{tabular}

\section{RESULTS}

\subsection{Pair-wise Comparison}

The basic statistical summary shows that the mean Z-Scores are higher for Islamic banks with the mean and median difference in Z-Score (CAR) and Z-Score (IR) being significant. This suggests that Islamic banks in Bangladesh are more stable than their conventional peers. The variability (in terms of $\mathrm{CV}$ ) in the stability measures of conventional banks suggests the presence of extreme values and we control for it in our regression analysis by taking log of the dependent variables.

The asset size and loan-asset ratio for Islamic banks are significantly higher than conventional banks although the assets of Islamic banks have higher variability. Because of this high variability and positively skewed distribution of the total assets, we also take log of total assets in the regression analysis. The high loan-asset ratio of Islamic banks indicates Islamic banks' non-involvement in interest based money market operations such as call-money market, T-Bills and this is also consistent with the literature (Beck et al., 2013; čihák \& Hesse, 2010). On the other hand, the cost-income ratio and income diversity of Islamic banks are significantly lower than conventional banks. Higher cost-income ratio for conventional banks indicates their relative cost inefficiency which is not in line with the existing literature (Beck et al., 2013; Čihák \& Hesse, 2010; Hassan, Mohamad, \& Khaled I. Bader, 2009; Rozzani \& Rahman, 2013). Higher income diversity indicates that conventional banks engage themselves more in other income generating activities. Čihák \& Hesse (2010) finds no significant difference in income diversity of both types of banks.

The summary statistics of the sample, 2005-2016 is given in the following. 
Table 5.

Summary Statistics

\begin{tabular}{|c|c|c|c|c|c|c|c|c|}
\hline Bank Type & Statistics & Z-Score & $\begin{array}{l}\text { Z-Score } \\
\text { (CAR) }\end{array}$ & $\begin{array}{l}\text { Z-Score } \\
\text { (IR) }\end{array}$ & $\begin{array}{l}\text { Total Assets } \\
\text { (Amount in } \\
\text { mn BDT) }\end{array}$ & $\begin{array}{l}\text { Loan- } \\
\text { Asset } \\
\text { Ratio }\end{array}$ & $\begin{array}{l}\text { Cost- } \\
\text { Income } \\
\text { Ratio }\end{array}$ & $\begin{array}{l}\text { Income } \\
\text { Diversity }\end{array}$ \\
\hline \multirow{5}{*}{ 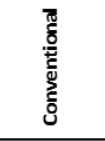 } & No. of Observations & 276 & 275 & 275 & 276 & 276 & 275 & 275 \\
\hline & Mean & 32.52 & 46.92 & 53.73 & $117,403.50$ & 67.12 & 44.23 & 66.47 \\
\hline & Median & 27.21 & 35.94 & 50.68 & $99,250.18$ & 68.11 & 43.19 & 64.32 \\
\hline & Standard Deviation & 26.57 & 41.03 & 20.04 & $77,093.95$ & 6.41 & 11.85 & 13.92 \\
\hline & Coefficient of Variation & 0.82 & 0.87 & 0.37 & 0.66 & 0.10 & 0.27 & 0.21 \\
\hline \multirow{5}{*}{$\frac{\underline{\underline{\underline{E}}}}{\underline{\underline{\underline{n}}}}$} & No. of Observations & 72 & 71 & 72 & 72 & 72 & 72 & 72 \\
\hline & Mean & 34.37 & 52.36 & 59.47 & $158,721.10$ & 73.85 & 40.10 & 45.69 \\
\hline & Median & 28.41 & 46.46 & 56.30 & $123,607.00$ & 74.37 & 38.93 & 44.42 \\
\hline & Standard Deviation & 21.06 & 31.82 & 14.16 & $162,505.30$ & 4.92 & 10.79 & 16.87 \\
\hline & Coefficient of Variation & 0.61 & 0.61 & 0.24 & 1.02 & 0.07 & 0.27 & 0.37 \\
\hline \multirow{2}{*}{ 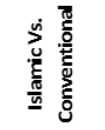 } & Mean Difference & 1.86 & $5.44 * *$ & $5.74 * * *$ & $41,317.6^{* *}$ & $6.73^{* * *}$ & \multicolumn{2}{|c|}{$(4.13)^{* * *}(20.78)^{* * *}$} \\
\hline & Median Difference & 1.21 & $10.52^{* *}$ & $5.62^{* * *}$ & $24,356.2^{* *}$ & $6.26 * * *$ & $(4.27)^{* * *}$ & $(19.9)^{* * *}$ \\
\hline
\end{tabular}

\subsubsection{Correlation Analysis of Stability Measures}

The correlation between the stability measures used in this study is expected to indicate whether the stability measures measure the same thing i.e. financial stability. If all the measures used in the study measures the same thing, the Z-Scores will be highly positively correlated with each other. But this is not the case as shown by the correlation matrix in the following. The Z-Score (ROAA) and Z-Score (CAR) are highly positively correlated meaning that they measure the same thing. But the Z-Score (ROAA) and Z-Score $(C A R)$ are positively correlated with Z-Score (IR) with the correlation being low.

Table 6

Correlation analysis

\begin{tabular}{lccc}
\hline & $\begin{array}{l}\text { Z-Score } \\
\text { (ROAA) }\end{array}$ & $\begin{array}{l}\text { Z-Score } \\
\text { (CAR) }\end{array}$ & Z-Score (IR) \\
\hline Z-Score (ROAA) & 1.0000 & & \\
Z-Score (CAR) & 0.9538 & 1.0000 & \\
Z-Score (IR) & 0.1054 & 0.0884 & 1.0000 \\
\hline
\end{tabular}




\subsubsection{Trend in Stability Measures Based On Bank Type}

The trend of stability measures over the study period is as follows:

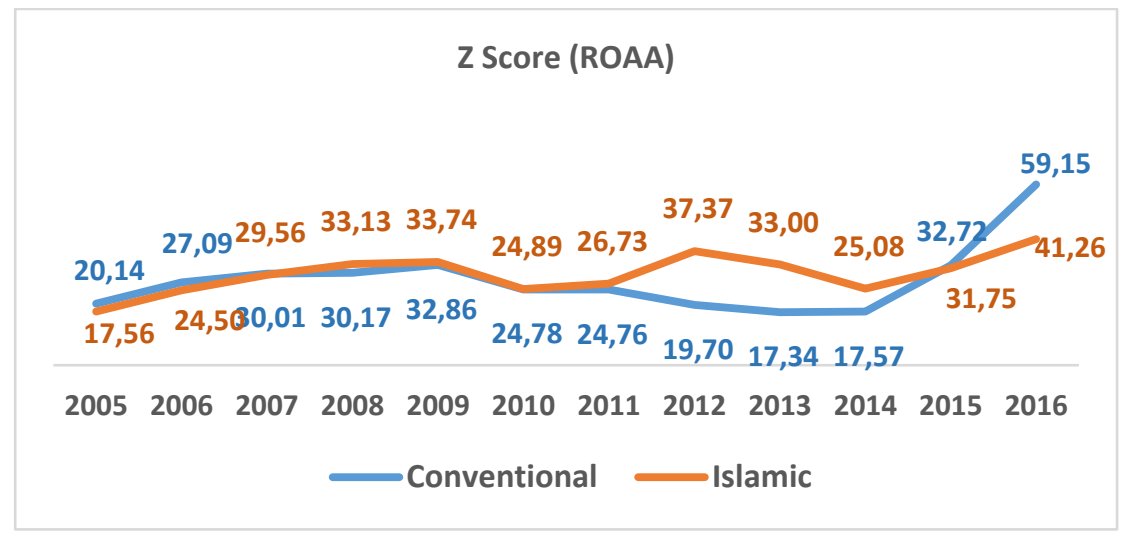

Figure 1.

Trend of Z Score (ROAA)

The above figure shows the yearly mean Z-Scores of both types of banks over the 12-year period. Z-Scores of Islamic banks varied from 17.56 in 2005 to 41.26 in 2016 whereas that of conventional banks varied from 20.14 to 59.15. During 2005-2008 IB's average ROAA in each of the year was very lower than CB's compared to the later years. During the same period, IB's average standard deviation of ROAA in each of the years was also lower than CB's compared to later years. That made the IBs relatively unstable, as indicated by the low Z-Score, in the initial years of the study period. The CBs were more stable in the last year as their ROAA, on an average, were less volatile than the earlier years.

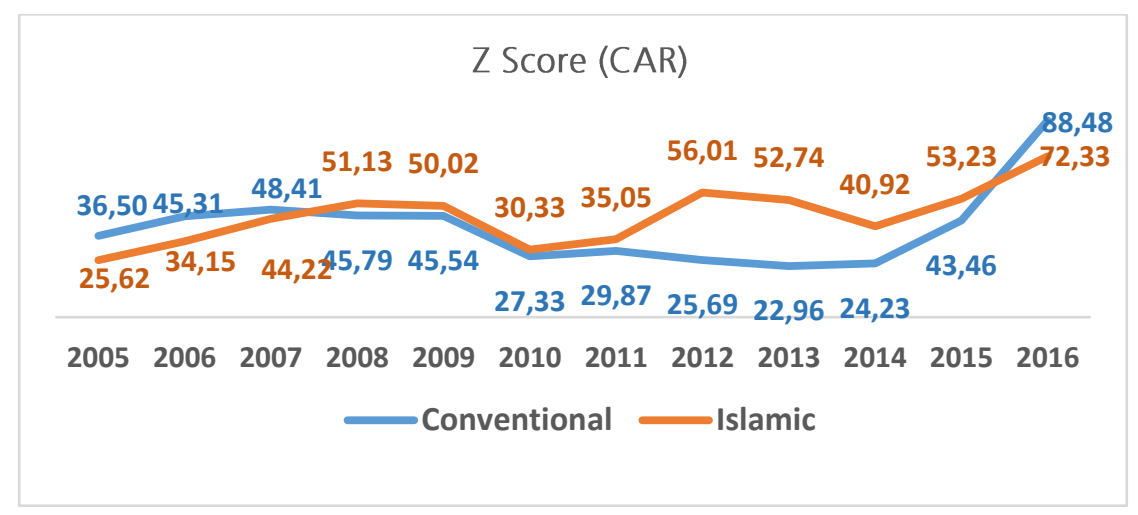

Figure 2.

Trend of Z Score (CAR) 
The above figure depicts the trend of mean Z-Score (CAR) of both types of banks during the study period. The graph almost assimilates the ZScore (ROAA) where IBs were relatively more stable from CBs from 2008 to 2015. The stability difference between the two types of banks in this measure is higher than that of Z-Score (ROAA). The reason might be that the Z-Score (ROAA) is based on Equity-Asset ratio which was on an average higher for Conventional banks in all the years except the period 2007-2009 and the Z-Score (CAR) is based on CAR (in place of Equity-Asset ratio) which was, on an average, higher for Islamic banks in all the years except the 2005, 2006, 2007 and 2016.

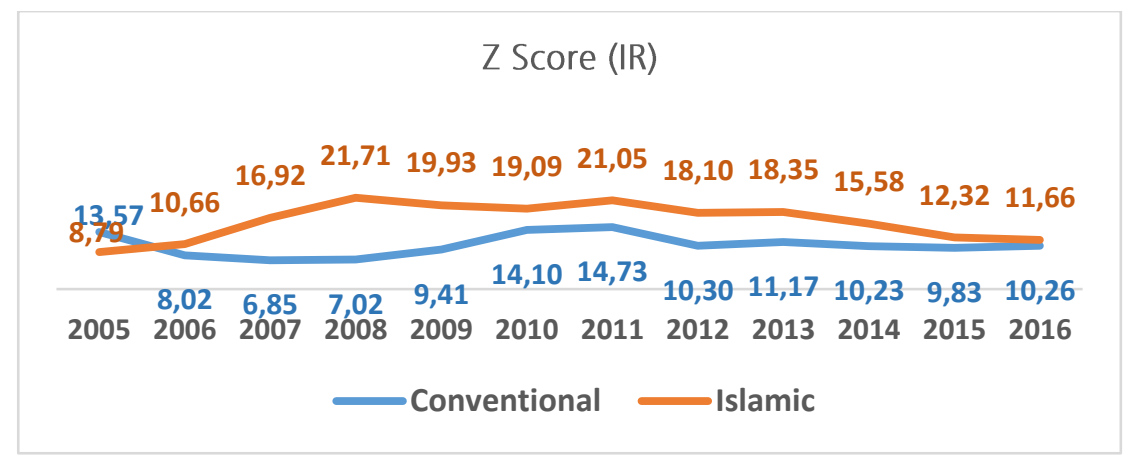

Figure 3.

Trend of Z Score (IR)

The above figure depicts the trend of mean Z-Score (IR) of both types of banks during the study period. From 2006, the scores of Islamic Banks have been consistently higher than those of the conventional banks and like the Z-Score (ROAA), the difference has declined substantially in the later years as IBs' relative stability declined. IBs' scores declined during the later years as their IR volatility (in terms of standard deviation) was increasing and the capital component (K) was declining.

\subsection{Static and Dynamic Panel Data Analysis}

In order to separate the impact on financial stability of banks from bank specific, industry and macro level characteristics, we perform static and dynamic panel regression. Each table given below contains 10 panel regressions of each type of Z-Score. The first five regressions in each table are the results from random effects technique and the last five are the results from System GMM technique. 
The coefficient of Islamic Bank dummy is significantly positive in only 2 random effects panel regressions of $Z$ score (based on IR) implying that Islamic banks are relatively more financially stable than their conventional counterparts. It is observed that the sign of the Islamic bank dummy is inconsistent in some regressions. However, they are not statistically significant.

The sign of the log of total asset variable is significantly positive in 6 regressions and significantly negative in 6 regressions. This doesn't give any conclusive idea on the impact of the bank size on stability. The loan-asset ratio consistently does not have the expected negative sign (Čihák \& Hesse, 2010). The sign is positive in almost all of the regressions of Z-Scores and significant in 8 regressions. The cost-income ratio has the expected negative sign and is significant in almost all panel regressions. The income diversity variable is not significant in the regressions of Z-Score (ROAA) and Z-Score (CAR). But it is consistently negative and significant in 2 regressions of ZScore (IR) indicating that the diversity of income decreases financial stability in terms of Z-Score (IR).

The sign of the share of Islamic banks variable is positive as well as significant in 4 regressions. This indicates that IBs increasing presence might increase the stability of the overall banking system. The sign of the interaction between share of Islamic banks and conventional bank dummy is inconsistent but significant and positive in 2 regressions of Z-Score (IR), indicating that Islamic banks' higher market share increases the financial stability of conventional banks. The sign of $\mathrm{HHI}$ is inconsistent overall but negative and significant in all the 4 regressions of $Z$ Score (IR) meaning that higher concentration reduces financial stability. This is consistent with the existing literature on stability and HHI (Schaeck, Čihák, \& Wolfe, 2009)

As to the macroeconomic variables, the sign of the real GDP growth is significant and positive in 4 regressions of Z-Score (ROAA) and Z-Score (CAR). The inflation variable is negative and significant in 8 regressions of all Z-Scores. This implies that with the growth of the real economy, the stability of the banking system increases and with the increase in inflation, the stability of the banking system declines. 


\subsubsection{Dependent Variable: Log Z-Score (ROAA)}

\begin{tabular}{|c|c|c|c|c|c|c|c|c|c|c|}
\hline Variable & $\mathrm{RE}_{-} 1$ & $\mathrm{RE}_{-} 2$ & $\mathrm{RE}_{-} 3$ & $\mathrm{RE}_{-} 4$ & $\mathrm{RE}_{-} 5$ & GMM_1 & GMM_ 2 & GMM_ 3 & GMM_4 & GMM_ 5 \\
\hline $\begin{array}{r}\text { Islamic Bank Dumny } \\
\text { LogTotalassets }\end{array}$ & .0225 & -.177 & .0225 & -.177 & .0225 & -.0131 & .0541 & -.0113 & .0168 & -.00577 \\
\hline $\begin{array}{r}\text { L1. } \\
\text { LoanAssetRatio }\end{array}$ & .154 & .133 & .154 & .133 & .154 & .0551 & $-.191^{\star \star}$ & $.189 *$ & $-.137 *$ & .143 \\
\hline $\begin{array}{r}\text { L1. } \\
\text { CostIncomeRatio }\end{array}$ & .0011 & .00113 & .0011 & .00113 & .0011 & -.00093 & .0018 & .00094 & .00345 & .00293 \\
\hline $\begin{array}{r}\text { L1. } \\
\text { IncomeDiversity }\end{array}$ & $-.00479 * * *$ & $-.00479 \star \star \star x$ & $-.00479 \star \star \star$ & $-.00479 * \star \star$ & $-.00479 \star \star \star$ & $-.00347 *$ & $-.00377 \star \star$ & -.00315 & $-.00509 * \star *$ & $-.00447^{\star \star}$ \\
\hline $\begin{array}{r}\text { L1. } \\
\text { ShareofIslamicBanks }\end{array}$ & .00029 & .00061 & .00029 & .00061 & .00029 & -.00037 & $9.1 \mathrm{e}-05$ & $-2.1 \mathrm{e}-05$ & .00105 & .00091 \\
\hline $\begin{array}{r}\text { L1. } \\
\text { Shareof Is lamicBanksCommerciB }\end{array}$ & & .0403 & & -.01 & & & $.04 \star \star$ & & $.0391 * \star$ & \\
\hline $\begin{array}{l}\text { L1. } \\
\text { HHI }\end{array}$ & & -.012 & & -.012 & & & .00354 & & .00126 & \\
\hline $\begin{array}{r}\text { L1. } \\
\text { GrowthinRealGDP }\end{array}$ & & & -.00049 & & .00033 & & & .00033 & & $9.8 \mathrm{e}-05$ \\
\hline $\begin{array}{r}\text { L1. } \\
\text { InflationRate }\end{array}$ & & & & -.306 & -.264 & & & & $.0689 * * *$ & $.0654^{* \star *}$ \\
\hline $\begin{array}{r}\text { L1. } \\
\text { LogZScore }\end{array}$ & & & & $-.374 * *$ & $-.344 * \star \star$ & & & & $-.0152 * *$ & $-.0189 * \star \star+$ \\
\hline $\begin{array}{r}\text { L1. } \\
\text { Constant }\end{array}$ & .814 & .498 & 1.22 & 5.84 & $4.7 *$ & $\begin{array}{l}.719 * * \star \\
.395\end{array}$ & $\begin{array}{l}.735^{* * *} \\
.633\end{array}$ & $\begin{array}{l}.733 * \star \star \\
-.642\end{array}$ & $\begin{array}{l}.71 * * * \\
.0248\end{array}$ & $\begin{array}{l}.706^{\star \star \star} \\
-.647\end{array}$ \\
\hline $\mathrm{N}$ & 318 & 318 & 318 & 318 & 318 & 318 & 318 & 318 & 318 & 318 \\
\hline
\end{tabular}

\subsubsection{Dependent Variable: Log Z-Score (CAR)}

\begin{tabular}{|c|c|c|c|c|c|c|c|c|c|c|}
\hline Variable & RE_ 1 & $\mathrm{RE}_{-} 2$ & $\mathrm{RE}_{-} 3$ & $\mathrm{RE}_{-} 4$ & $\mathrm{RE}_{-} 5$ & GMM_1 & GMM_ 2 & GMM_ 3 & GMM_4 & GMM_ 5 \\
\hline Islamic Bank Dumny & .053 & -.33 & .053 & -.33 & .053 & .0471 & .0338 & .0602 & -.0528 & .0657 \\
\hline $\begin{array}{r}\text { LogTotalAssets } \\
\text { L1. }\end{array}$ & $.241 *$ & .2 & $.241 *$ & .2 & $.241 *$ & .0825 & $-.252 *$ & $.243 * *$ & -.188 & .159 \\
\hline \multicolumn{11}{|l|}{ LoanAssetRatio } \\
\hline \multicolumn{10}{|l|}{ CostincomeRatio } & .00464 \\
\hline \multicolumn{10}{|c|}{ IncomeDiversity } & -.00527 \\
\hline L1. & .00015 & .00075 & .00015 & .00075 & .00015 & $-9.2 e-05$ & $-4.9 e-05$ & .00041 & .00132 & .0017 \\
\hline \multicolumn{11}{|l|}{ ShareofIs lamicBanks } \\
\hline L1. & & .0369 & & -.0153 & & & $.055 *$ & & $.0587 * *$ & \\
\hline \multicolumn{11}{|l|}{ Shareof IslamicBanksCommerciB } \\
\hline L1. & & -.023 & & -.023 & & & .00148 & & -.00379 & \\
\hline HHI & & & & & & & & & & \\
\hline L1. & & & -.00023 & & .00057 & & & .00039 & & $-2.4 e-05$ \\
\hline \multicolumn{11}{|l|}{ GrowthinRealGDP } \\
\hline L1. & & & & -.264 & -.192 & & & & $.111 * * *$ & $.117 * * *$ \\
\hline \multicolumn{11}{|l|}{ InflationRate } \\
\hline L1. & & & & $-.387 * *$ & $-.335 * *$ & & & & -.0114 & $-.0186^{* * *}$ \\
\hline \multicolumn{11}{|l|}{ Log ZScoreCAR } \\
\hline L1. & & & & & & $.655^{* * * *}$ & $.704 * * *$ & $.668^{* * * *}-1$ & $.666^{* * * *}$ & $.638 * * *$ \\
\hline Constant & .637 & .598 & .825 & 5.78 & 3.78 & .337 & .805 & -.919 & -.193 & -.974 \\
\hline N & 318 & 318 & 318 & 318 & 318 & 317 & 317 & 317 & 317 & 317 \\
\hline
\end{tabular}




\subsubsection{Dependent Variable: Log Z-Score (IR)}

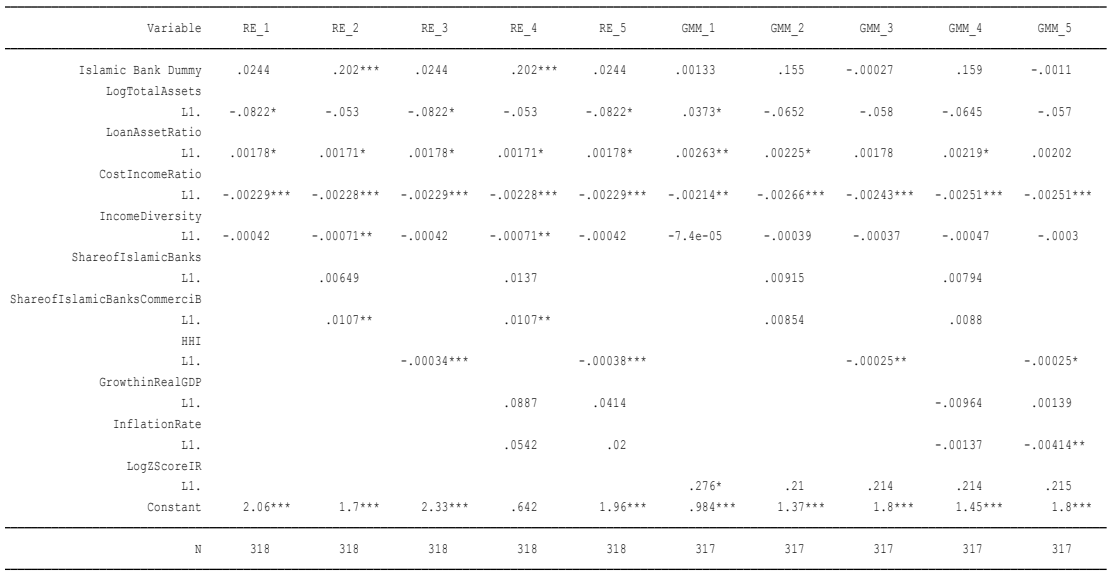

\section{CONCLUSION}

In this study, we analyse the stability of Islamic banks operating in Bangladesh, using different financial stability measures that include a new stability measure (Z-Score based on loan infection ratio) developed for the first time in this study. We also analyse the presence of Islamic banks on the financial stability of the overall banking system as well as the conventional banks in Bangladesh. In pairwise comparison of means, we find that Islamic banks are financially more stable in two stability measures i.e. Z-Score (CAR) and Z-Score (IR). Moreover, controlling for Bank, Industry and Macroeconomic variables in our regressions of different Z-Scores, we find that Islamic banks are financially more stable in two of our panel regressions of Z-Score (IR). The study also reveals that the presence of Islamic banks increases the stability of all banks in the system as well as the stability of their conventional peers.

The findings of the study could be more robust provided that we could address a few limitations. We could not separate the Islamic windows of conventional banks in our analysis because of non-availability of data for Islamic windows, the inclusion of which could give more interesting findings. Although we considered non listed state-owned banks in calculating $\mathrm{HHI}$, the study is based on listed commercial banks only because of the availability of data. Further studies can attempt to include Islamic window banks, foreign and state owned commercial banks in the data set. As to the new stability measure developed in this study, the effectiveness of this measure in reflecting the true financial stability of banks can be empirically tested on cross-country basis in future studies. 


\section{REFERENCES}

Abedifar, P., Molyneux, P., \& Tarazi, A. (2013). Risk in islamic banking. Review of Finance, 17(6), 2035-2096.

Allen, W. A., \& Wood, G. (2006). Defining and achieving financial stability. Journal of Financial Stability, 2(2), 152-172.

Beck, T., Demirgüç-Kunt, A., \& Merrouche, O. (2013). Islamic vs. conventional banking: Business model, efficiency and stability. Journal of Banking and Finance, 37(2), 433-447.

Bourkhis, K., \& Nabi, M. S. (2013). Islamic and conventional banks' soundness during the 2007-2008 financial crisis. Review of Financial Economics, 22(2), 68-77.

Boyd, J. H., \& Runkle, D. E. (1993). Size and performance of banking firms. Testing the predictions of theory. Journal of Monetary Economics, 31(1), 47-67.

Chong, B. S., \& Liu, M. H. (2009). Islamic banking: Interest-free or interestbased? Pacific Basin Finance Journal.

Čihák, M., \& Hesse, H. (2010). Islamic Banks and Financial Stability: An Empirical Analysis. Journal of Financial Services Research, 38(2), 95113.

European Central Bank. (2015). Financial Stability Review, November 2015.

Retrieved from https://www.ecb.europa.eu/pub/pdf/other/financialstabilityreview20 1511.en.pdf

Farook, S., Hassan, M. K., \& Clinch, G. (2015). Islamic banks and Financial Stability: Further Evidence, 1-43.

Hassan, T., Mohamad, S., \& Khaled I. Bader, M. (2009). Efficiency of conventional versus Islamic banks: evidence from the Middle East. International Journal of Islamic and Middle Eastern Finance and Management, 2(1), 46-65.

Jobst, A. a. (2008). Derivatives in Islamic Finance. Islamic Capital Markets Products, Regulation \& Development.

Laeven, L., \& Levine, R. (2009). Bank governance, regulation and risk taking. Journal of Financial Economics. 
Lepetit, L., Nys, E., Rous, P., \& Tarazi, A. (2008). Bank income structure and risk: An empirical analysis of European banks. Journal of Banking and Finance.

Maechler, A., Mitra, S., \& Worrel, D. (2005). Exploring Financial Risks and Vulnerabilities in New and Potential EU Member States, (June 2016).

Rajhi, W., \& Hassairi, S. A. (2013). Islamic Banks and Financial Stability: A Comparative Empirical Analysis Between MENA and Southeast Asian Countries. Région et Développement, 37, 1-31.

Rozzani, N., \& Rahman, R. A. (2013). Determinants of Bank Efficiency: Conventional versus Islamic. International Journal of Business and Management, 8(14), 98-110.

Schaeck, K., Čihák, M., \& Wolfe, S. (2009). Are More Competitive Banking Systems More Stable? Retrieved from https://www.imf.org/external/pubs/ft/wp/2006/wp06143.pdf

Uddin, A., Chowdhury, M. A. F., \& Islam, M. N. (2017). Resiliency between Islamic and conventional banks in Bangladesh: Dynamic GMM and quantile regression approaches. International Journal of Islamic and Middle Eastern Finance and Management.

Van Greuning, H., \& Iqbal, Z. (2008). Risk analysis for Islamic banks. World Bank Publications. 
314 Financial Stability of Islamic and Conventional Banks in Bangladesh: Revisiting Stability Measures and Analyzing Stability Behavior

This page is intentionally left blank 